\title{
A comparative study of Delhi and Vidarbha on academic achievement, sports performance, physical fitness and attitude towards physical education of Senior Secondary School students
}

Received : 09.06.2016; Revised : 11.09.2016; Accepted : 25.09.2016

Author for correspondence

UMESH RATHI

Arts College, Kurha, AMRAVATI (M.S.) INDIA

\section{-ABSTRACT}

The most important model for physical education in this century has been the development modern physical education through sports. Many people who aspire to a career in the sports and physical education profession had youth experiences in sports they were primary motivating factors. The present study found out Delhi and Vidarbha region on academic achievement, sports performance, physical fitness and attitude towards physical education of Senior Secondary School students. This study was delimited to the Senior Secondary School girls of Delhi and Vidarbha of girls of the age of 16 to 18 years. Methodology of the study 200 subjects Delhi and Vidarbha region. All 400 girls students had been collected data. AAHPHER physical fitness test and Dr. Beena Shah achievement scale questionnaire and attitude towards physical education and sports performance questionnaire of G.P. Thakur and Manju Thakur ware used to collect the data. The means and standard deviations were calculated and to see the effect of physical fitness on attitude toward physical education and sports and on academic achievements and sports performance ' $t$ ' test was applied.The study concluded that Delhi students compare Vidharba students better physical fitness in girl's students have better attitude toward physical education and sports, better academic achievements and better sports performance.

- KEY WORDS : Academic achievement, Sports performance, Physical fitness, Attitude of towards physical education

- HOW TO CITE THIS PAPER : Rathi, Umesh (2016). A comparative study of Delhi and Vidarbha on academic achievement, sports performance, physical fitness and attitude towards physical education of Senior Secondary School students. Internat. J. Phy. Edu., 9 (1\&2) : 21-24, DOI : 10.15740/HAS/IJPE/ 9.1\&2/21-24. 